УДК $658.8: 339.138$

DOI https://doi.org/10.32851/2708-0366/2020.4.14

Стручок Н.M.

кандидат економічних наук, доцент, завідувач кафедри міжнародної економіки та інвестиційної діяльності,

Львівський інститут економіки і туризму

Замрій O.M.

стариий викладач кафедри міжнародної менеджменту та комерційної діяльності

Львівський інститут економіки і туризму

Struchok Natalya, Zamrii Oksana

Lviv Institute of Economy and Tourism

\title{
СТРАТЕГІЧНІ ПІДХОДИ В УПРАВЛІННІ ЗБУТОМ ТОВАРІВ ТА ПОСЛУГ
}

\section{STRATEGIC APPROACHES IN SALES MANAGEMENT OF GOODS AND SERVICES}

У статті представлено аналіз поточного стану ринку роздрібної торгівлі в Україні. Здійснено огляд найпоширеніших роздрібних торговельних мереж в Украӥні, визначено ТОП-5 національних food-рітейлерів за загальним числом торгових точок. Окреслено стратегічні підходи в проиесі управління збутом товарів, послуг та обслуговування споживачів. Визначено тендениії розвитку торгових точок foоd-рітейлерів в розрізі регіонів України. Виокремлено роль маркетингових складових, принципів мерчандайзингу та інноваційних технологій як основних інструментів в управлінні проиесом збуту товарів, послуг споживачам сучасним торговельним підприємством. Визначено основні підходи в організації мерчандайзингу для торгового підприємства. Окреслено особливості інноваційної діяльності в роздрібній торгівлі Украӥни.

Ключові слова: торгівля, мережі, торговельне підприємство, стратегічне управління, мерчандайзинг, складові комплексу маркетингу, інноваційні технології.

В статье представлен анализ текущеего состояния рынка розничной торговли в Украине. Осуществлен обзор самых распространенных розничных торговых сетей в Украине, определены ТОП-5 национальных food-ритейлеров по общзему числу торговых точек. Onределены стратегические подходы в проиессе управления сбытом товаров, услуг и обслуживания потребителей. Определены тенденции развития торговых точек foоd-ритейлеров в разрезе регионов Украины. Вылделень роль маркетинговых составляющих, принципов мерчандайзинга и инновационных технологий как основных инструментов в управлении процессом сбыта товаров, услуг потребителям современным торговым предприятием. Определены основные подходы в организаичи мерчандайзинга для торгового предприятия. Определены особенности инновациинной деятельности в розничной торговле Украинь.

Ключевые слова: торговля, сети, торговое предприятие, стратегическое управление, мерчандайзинг, составляющце комплекса маркетинга, инновационные технологии.

The article presents an analysis of the current state of the retail market in Ukraine. The main purpose of the article is to determine the main components in the strategic management of sales of goods, services and customer service of modern commercial enterprises. A review of the most common retail chains in Ukraine, identified the TOP-5 national food retailers by total number of outlets. Strategic approaches in the process of sales management of goods, services and customer service are outlined. Trends in the development of food retailers in the context of the regions of Ukraine are identified. The role of marketing components, principles of merchandising and innovative technologies as the main tools in management of process of sale of the goods, services to consumers by the modern trading enterprise is allocated. Argumentative innovative service technologies allow commercial enterprises not only to occupy leading positions in their market segments, but also to meet global approaches in the organization and conduct of trade. 
It is determined by the results of the study that merchandising should be interpreted as a set of methods and techniques combined to enhance the role of the product in the sales process by optimizing its performance and environment and thus increase its profitability. The basic approaches in the organization of merchandising for the trading enterprise are defined. Peculiarities of innovative activity in retail trade of Ukraine are outlined. The components of innovation activity in retail trade are defined: innovations which are directed on introduction of changes in the course of realization of the goods, the innovations connected with management and the organization of all processes at the trading enterprise, improvement of working conditions by automation of many processes and creation of conveniences in household needs. Related to personnel management and aimed primarily at improving their motivation and skills. Merchandising rules, components of the marketing complex and innovative technologies should remain an integral part of the strategic management of the process of sales of goods, services and customer service of trade enterprises.

Key words: trade, networks, trade enterprise, strategic management, merchandising, components of marketing complex, innovative technologies.

Постановка проблеми. Комерційна діяльність торговельних підприємств в досить мінливих та складних умовах розвитку соціально-економічних процесів країни неможлива без побудови чіткої стратегічної концепції в організації всієї виробничої діяльності, в тому числі в організації збуту товарів та послуг споживачам, з метою якнайповнішого задоволення їх потреб і забезпечення високої якості обслуговування.

Якість торгового обслуговування залежить від широти наявного торгового асортименту, оптимально зручної та зрозумілої викладки товарів в торговому залі, ефективного подання товарів, дотримання правил їх продажу та заходів, спрямованих на створення загальної атмосфери підприємства.

Провідні торговельні підприємства в процесі стратегічного управління застосовують в процесі збуту товарів та послуг підходи, побудовані на правилах мерчандайзингу, ефективного використання складових комплексу маркетингу, впровадження досягнень науково-технічного прогресу, нових інноваційні технології в процес продажу товарів та обслуговування, використовуючи передовий світовий досвід.

Аналіз останніх досліджень і публікацій. Проблемам стратегічного управління в управління збутом товарів та послуг присвячені праці вітчизняних та іноземних вчених - науковців як, I. Ансофф, К. Брацн, П.Дракер, Д. Ланкастер, Д. Джоббер, В. Василенко, О.Вовчак, О.Скібіцький, І.Наливайко, 3. Шершньова, Б. Мізюк, Ф.Котлер інші. Проте умови та потреби ринку сьогодення вимагають інноваційних підходів в управлінні збутом товарів та послуг.

Інноваційні технології обслуговування дають змогу торговельним підприємствам не тільки займати лідируючі позиції у своїх ринкових сегментах, але й відповідати світовим підходам в організації і веденні торгівлі.

Формулювання цілей статті. Головною метою статті $\epsilon$ визначення основних складових в стратегічному управлінні збутом товарів, послуг та обслуговування споживачів сучасних торговельних підприємств.

Виклад основного матеріалу. Однією з найважливіших галузей та сфер економіки України, від якої значно залежить якість життя населення, є торгівля.

Торгівля - це будь-які операції, що здійснюються за договорами купівлі-продажу, міни, поставки та іншими цивільно-правовими договорами, які передбачають передачу прав власності на товари [1].

Динамічний розвиток торгівлі підтверджується статистичними даними, 3 яких видно, що товарооборот внутрішньої торгівлі має тенденцію до зростання (табл.1). За досліджуваний період відслідковується зростання індексу роздрібного товарообороту підприємств роздрібної торгівлі у 2016 і 2017 роках на 15,5 \% та зниження у 2018 році до рівня $12 \%$. Стрімко зростає обсяг роздрібного товарообороту підприємств роздрібної торгівлі на одну особу з 11612,3 грн у 2013 році до 39220,0 грн. у 2018 році. 
Таблиця 1

Товарооборот торгівлі в Україні у 2013-2018 рр.

\begin{tabular}{|l|c|c|c|c|c|c|}
\hline & $\mathbf{2 0 1 3}$ & $\mathbf{2 0 1 4}$ & $\mathbf{2 0 1 5}$ & $\mathbf{2 0 1 6}$ & $\mathbf{2 0 1 7}$ & $\mathbf{2 0 1 8}$ \\
\hline $\begin{array}{l}\text { Оптовий товарооборот } \\
\text { підприємств оптової торгівлі, } \\
\text { млн. грн. }\end{array}$ & 32886,0 & 35458,1 & 27627,1 & 26038,6 & 30958,4 & 45420,6 \\
\hline $\begin{array}{l}\text { Роздрібний товарооборот } \\
\text { підприємств роздрібної торгівлі, } \\
\text { млн. грн. }\end{array}$ & 8810,3 & 11257,2 & 14580,9 & 18664,2 & 24231,9 & 29685,6 \\
\hline $\begin{array}{l}\text { Індекси роздрібного } \\
\text { овварообороту підприємств } \\
\text { роздрібної торгівлі, } \\
\text { відсотків до попереднього року }\end{array}$ & $\ldots$ & 105,3 & 93,3 & 115,6 & 115,5 & 112,0 \\
\hline $\begin{array}{l}\text { Роздрібний товарооборот } \\
\text { підприємств роздрібної торгівлі } \\
\text { на одну особу, грн. }\end{array}$ & 11612,3 & 14837,5 & 19218,3 & 24609,9 & 31959,7 & 39220,0 \\
\hline
\end{tabular}

Джерело: сформовано на основі [2]

Особливу роль в організації торгівлі відведено роздрібній торгівлі, яка здійснює доведення товарів зі сфери виробництва до сфери кінцевого споживача.

Розвиток роздрібної торгівлі значною мірою залежить від кількості об'єктів роздрібної торгової мережі, форм їх організації та спеціалізації, рівня забезпеченості ним населення [3, с. 248-253].

Вітчизняний роздрібний ринок демонструє сьогодні велику кількість як закордонних («Metro Cash\&Carry» (Німеччина), «Billa» (Австрія), «Аuchan» (Франція), «Novus» (Литва) та інші), так і вітчизняних мереж, які перебувають у постійній боротьбі за покупця і продовжують збільшувати кількість своїх торгових точок [4].

ТОП-5 національних food-рітейлерів за загальним числом торгових точок відображено у таблиці 2.

Таблиця 2

ТОП-5 національних food-рітейлерів

\begin{tabular}{|c|c|c|c|c|c|c|}
\hline № & Компанія & Мережі & $\begin{array}{c}\text { Цент- } \\
\text { ральний } \\
\text { офіс }\end{array}$ & $\begin{array}{c}\text { Кількість } \\
\text { торгових } \\
\text { точок, } \\
2018 \text { р. }\end{array}$ & $\begin{array}{c}\text { Кількість } \\
\text { торгових } \\
\text { точок, } \\
2017 \text { р. }\end{array}$ & $\begin{array}{c}\text { Приріст } \\
2018 \text { р. - } \\
2017 \text { pp., \% }\end{array}$ \\
\hline 1 & $\begin{array}{l}\text { ТОВ } \\
\text { «АТБ -маркет» }\end{array}$ & АТБ, АТБ ekspres & Дніпро & 990 & 910 & 8,8 \\
\hline 2 & FOZZY Group & $\begin{array}{l}\text { Сільпо, Фора, } \\
\text { FOZZY, } \\
\text { Le Silpo,Thrashl, } \\
\text { Favore }\end{array}$ & Київ & 540 & 534 & 1,1 \\
\hline 3 & $\begin{array}{l}\text { Volwest } \\
\text { Group }\end{array}$ & $\begin{array}{l}\text { Наш Край, } \\
\text { SPAR Наш Край } \\
\text { ЕКСПРЕС }\end{array}$ & Луцьк & 248 & 245 & 1,2 \\
\hline 4 & $\begin{array}{l}\text { ООО ТПК } \\
\text { «Львівхолод» }\end{array}$ & $\begin{array}{l}\text { Рукавичка, Під Боком, } \\
\text { Рукавичка S }\end{array}$ & Львів & 141 & 131 & 7,6 \\
\hline 5 & ТОВ «ЕКО» & $\begin{array}{l}\text { ЕКО маркет, } \\
\text { Симпатик }\end{array}$ & Київ & 114 & 114 & 0,0 \\
\hline
\end{tabular}

Джерело: сформовано на основі [4] 
Серед Топ-5 продуктових мереж перше місце впевнено займає Дніпровська мережа дискаунтерів АТБ, потужність якої яка станом на 31 грудня 2018 року становила 990 торгових точок. За рік лідер продуктового рітейлу країни збільшив мережу на 80 магазинів. На другій позиції утримується Fozzy Group, що розвиває бренди Сільпо, Le Silpo, Favore, Thrash. За минулий рік компанія збільшила свій портфель на 5 магазинів.

Слід зазначити, що двійка лідерів географічно присутня у всіх регіонах України, а компанії, які зайняли третє і четверте місця, основну свою увагу зосередили на Західній Україні.

Volvest Group - один з небагатьох продуктових операторів, які обрали шлях розвитку мережі по франчайзингу, в тому числі такому екзотичному для нашої країни, як зворотний франчайзинг. За рік компанія збільшила кількість своїх торгових точок лише на три, але активно працює над впровадженням нових форматів і пропозицією покупцям нових сервісів.

Західноукраїнська група - Львівхолод, бренд Рукавичка - за рік зросла на десять об'єктів, до 141-го магазину, та продовжує залишатися провідним регіональним FMCG-рітейлером Львівської та деяких прилеглих областей.

Компанія ЕКО маркет, що замикає дану п'ятірку, у 2018 році формально не збільшила кількість своїх магазинів, але оновлювала торгові точки та впроваджувала нові технології (рис.1).

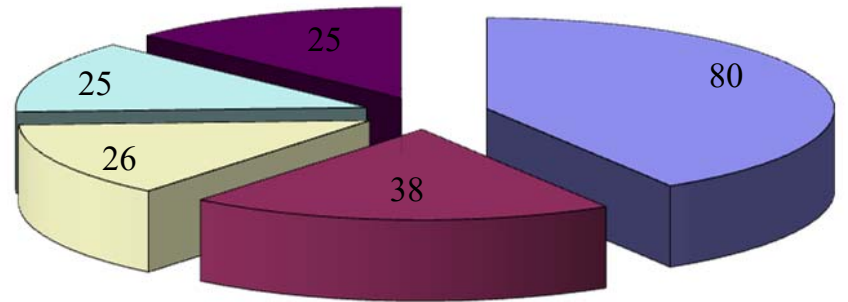

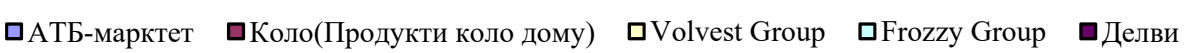

Рис. 1. ТОП-5 рітейлерів за кількістю відкриттів у 2018 роцฺі

Джерело: сформовано на основі [4]

Регіони України, де відкривалися FMCG магазини відображено на рис. 2. У західному регіоні, зокрема у великих містах, зосереджена велика кількість сучасних торгових форматів, в тому числі супермаркетів, гіпермаркетів, Cash\&Carry та торгових центрів (у м. Львові здійснюють комерційну діяльність як багатофункціональні торгові центри: King Cross Leopolis, Viktoria Gardens, Forum Lviv, Магнус, Опера Пасаж, Роксолана, Інтер Сіті, Скриня, так і спеціалізовані - Метро, Ашан, Епіцентр, Три Слони, Марк, Нова Лінія, Гора та інші.)

Жорстка конкуренція серед комерційних структур, можливість захоплення даної сфери з боку іноземних інвесторів, перевагою яких $є$ володіння значними капіталами, вимагає від власників торговельного бізнесу побудови чіткої стратегічної концепції побудованої на засадах маркетингу в організації системи збуту, а саме створення переліку додаткових сервісних послуг, програм лояльності до постійних клієнтів, заходів, що сприяють залученню нових покупців. 


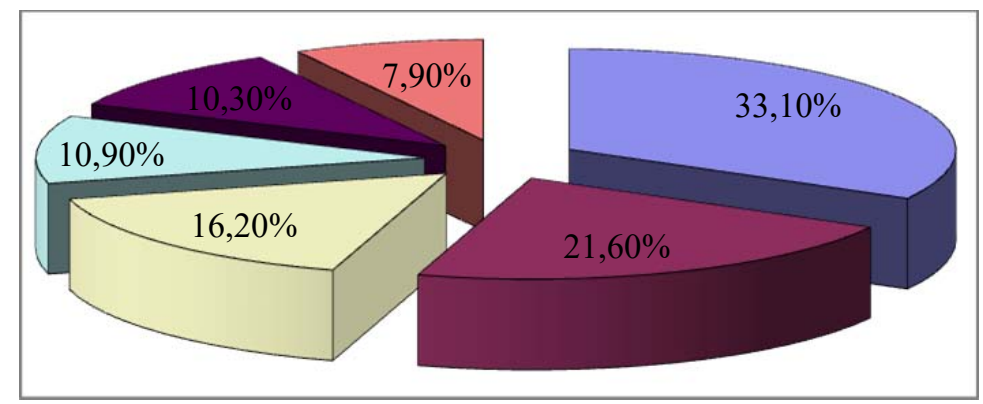

\begin{tabular}{|lll|}
\hline 口Західна Україна & 口Східна Україна & 口Киів \\
口Північна Україна & Фівденна Україна & 口Центральна Україна \\
\hline
\end{tabular}

Pис. 2. Частка регіонів України у структурі системи збуту FMCG у 2018 роиі, \% Джерело: сформовано на основі [4]

У свою чергу, наявність великого вибору варіантів торговельних об'єктів робить сучасних українців більш вибагливими до здійснення покупок, підсилює бажання отримати додаткові сервісні послуги при мінімальних витратах часу та грошей.

На сьогоднішній день $з$ боку комерційних структур спостерігається удосконалення та збільшення спектра послуг, сервісів, орієнтованих на попит споживачів.

Для успішної діяльності торгівельного підприємства велике значення має організація мерчандайзингу, адже вибір покупців продиктований не лише рекламою і сформованими превагами, але й тим, як певний товар представлений у точці продажу.

Світовий досвід свідчить, що обсяги продажу товару можна збільшити майже на 400-600 \%, якщо просто правильно викласти товар [6, с. 126-131]. Згідно $з$ дослідженнями американського інституту РОРАІ 70\% рішень щодо купівлі товару конкретної марки приймаються вже в магазині. Тому саме в торговельній мережі, аби покращити обізнаність споживачів про товар та підвищити його збут, потрібно займатись мерчандайзингом.

Мерчендайзинг - сукупність методів і технік, об'єднаних з метою активізувати роль товару в процесі продажу з допомогою оптимізації його представлення та оточення і тим самим підвищити його рентабельність.

Основними підходами в організації мерчандайзингу для торгового підприємства є:

- асортиментний підхід. Для кожного типу роздрібного торговельного підприємства характерні певні значення показників асортименту з урахуванням встановлених керівництвом підприємства-виробника або продавця широти і глибини торгового асортименту;

- кількісний підхід. У роздрібному торговельному підприємстві необхідно підтримувати оптимальний рівень товарного запасу, тобто такий, який забезпечує наявність достатньої кількості товарів необхідного асортименту в торговому залі. Крім того, товари, виставлені у вітрині, повинні бути в продажу;

- управлінський підхід. Організація розміщення товарів у торговельному залі магазину повинна грунтуватися на управлінні рухом купівельного потоку і починатися з планування торгового залу магазину;

- демонстраційний підхід. Вибір способів представлення товарів в торговому залі магазину, виду товару, упаковки, а також прибутку від товару, іміджу магазина, купівельної аудиторії;

- комунікаційний підхід. Рекламні матеріали на місці продажу є істотною частиною комунікаційної політики роздрібного торговельного підприємства і конструктивно-технічним елементом мерчандайзингу. 
Мерчандайзинг - це маркетинг в стінах магазину. Використання базового поняття «комплекс маркетингу» дає чітке визначення у визначенні задач мерчандайзингу, що подано у таблиці 3.

Таблиця 3

Завдання мерчандайзингу

\begin{tabular}{|l|l|}
\hline $\begin{array}{c}\text { Складові } \\
\text { комплекс } \\
\text { маркетингу }\end{array}$ & \multicolumn{1}{|c|}{ Завдання мерчандайзингу } \\
\hline Tовар & $\begin{array}{l}\text { Прийнятяя рішень з формування асортименту (адаптація асортименту до ви- } \\
\text { мог споживача), методи представлення, розміщення і викладки товарів в тор- } \\
\text { говому залі. }\end{array}$ \\
\hline Ціна & $\begin{array}{l}\text { Удосконалення цінової стратегії, здійснення глибокої цінової політики в про- } \\
\text { цесі закупки. } \\
\text { Покращення логістичного сервісу для магазинів (виробники). }\end{array}$ \\
\hline Місце & $\begin{array}{l}\text { Створення неповторної атмосфери магазину, використання комбінації засобів } \\
\text { архітектури, дизайну і сенсорної стимуляції. Планування магазину, відділів, } \\
\text { секцій для найбіш повної привабливості споживачів. }\end{array}$ \\
\hline Просування & $\begin{array}{l}\text { Удосконалення видів і способів використання реклами та інформації в місцях } \\
\text { продажу товарів. } \\
\text { Консультування про основні властивості та переваги товарів і специфіка об- } \\
\text { слуговування. Переконання споживачів про високу якість товарів, що є в реа- } \\
\text { лізації. Робота по популяризації конкретних товарів в магазині. }\end{array}$ \\
\hline
\end{tabular}

Джерело: сформовано на основі [7]

Основними напрямами сучасного динамічного розвитку роздрібних торговельних підприємств $€$ нововведення, інновації в управлінні процесом збуту та обслуговування споживачів, зокрема варто відзначити акцент на маркетингових інноваціях.

Маркетингові складові забезпечують максимальний збут продукції, досягнення значної активності комерційної діяльності та частки підприємства на ринку.

Інновація - це нововведення, нова, вдосконалена продукція або технологія, отримана в результаті інноваційного процесу, найважливішою iï складовою на торговельних підприємствах є вдосконалення технології торгівлі, яка являє собою сукупність робіт, що забезпечують реалізацію торгового процесу найбільш раціональними способами відповідно до конкретних господарських умов.

Інноваційна діяльність в роздрібній торгівлі відбувається за такими напрямами як: інновації, які спрямовані на впровадження змін у процесі реалізації товарів (зміна технології продажу, штрих-кодування, впровадження самообслуговування, електронної торгівлі); інновації, пов'язані з управлінням та організацією всіх процесів на торговельному підприємстві (автоматизація системи обліку, прийом та облік товарів, аналіз товароруху, документообіг, цінова та маркетингова політика, система врахування ризику та прийняття управлінського рішення); поліпшення умов праці шляхом автоматизації багатьох процесів і створення зручностей у побутових потребах; інновації, пов'язані з управлінням персоналом і спрямовані переважно на підвищення його мотивації та кваліфікації.

Інноваційні процеси в торгівлі знаходяться на етапі динамічного розвитку, про що свідчить широкий спектр інноваційних технологій, які використовуються підприємствами торгівлі.

В галузі роздрібної торгівлі застосовується: програмне забезпечення Back-Office; RFID (RadioFrequencyIdentification) - радіочастотна ідентифікація, яка може одночасно зчитувати інформацію різних груп товарів різної комплектації; штрих-коду і комп’ютерів. 
Особливості інноваційної діяльності в роздрібній торгівлі України відображені у таблиці 4.

Таблиця 4

Особливості інноваційної діяльності в роздрібній торгівлі України

\begin{tabular}{|c|c|c|}
\hline $\begin{array}{c}\text { Характерна } \\
\text { ознака }\end{array}$ & Характер прояву & Особливості \\
\hline $\begin{array}{l}\text { Роздрібна } \\
\text { торгівля } \\
\text { як вид } \\
\text { економічної } \\
\text { діяльності }\end{array}$ & $\begin{array}{l}\text { Основний продукт тор- } \\
\text { гівлі торговельна послу- } \\
\text { га, що має нематеріаль- } \\
\text { ний характер. Роздрібна } \\
\text { торгівля контактує } 3 \text { кін- } \\
\text { цевим споживачем, впли- } \\
\text { ває на поведінку великої } \\
\text { кількості людей. } \\
\text { Інформація, що одер- } \\
\text { жується під час контак- } \\
\text { ту зі споживачем, слугує } \\
\text { джерелом інновацій як } \\
\text { для сфери торгівлі, так і } \\
\text { для сектора промислово- } \\
\text { го виробництва. }\end{array}$ & $\begin{array}{l}\text { Основна частина інновацій в торгівлі } є \text { процес- } \\
\text { ними, маркетинговими, асортиментно-продук- } \\
\text { товими, організаційно-управлінськими. Значна } \\
\text { частина таких інновацій у торгівлі з'являється не } \\
\text { в результаті НДдКР (R\&D), а на основі маркетин- } \\
\text { гу, конкурентного аналізу, бенчмаркінгу, тощо. } \\
\text { Інноваційна активність сектора роздрібної тор- } \\
\text { гівлі не відображається офіційною статистикою, } \\
\text { інноваційна діяльність у сфері торгівлі не по- } \\
\text { требує високої стимулюючої ролі держави. Тор- } \\
\text { гівля впливає на інноваційну активність в інших } \\
\text { галузях економіки, передусім у промисловості. } \\
\text { У сфері роздрібної торгівлі створюються й впро- } \\
\text { ваджуються власні інновації, ініціюються і поши- } \\
\text { рюються інновації, започатковані в інших сферах } \\
\text { економіки, насамперед, у промисловості. }\end{array}$ \\
\hline $\begin{array}{l}\text { Особливості } \\
\text { організації } \\
\text { торговельної } \\
\text { діяльності }\end{array}$ & $\begin{array}{l}\text { Більшу частину суб'єк- } \\
\text { тів торгівлі становлять } \\
\text { малі й середні торго- } \\
\text { вельні підприємства, що } \\
\text { часто першими почина- } \\
\text { ють продаж нових това- } \\
\text { рів, виробники яких ще } \\
\text { не досягли необхідного } \\
\text { масштабу для створення } \\
\text { широкої дистрибуції й } \\
\text { виходу в роздрібні мере- } \\
\text { жі. Водночас швидкими } \\
\text { темпами зростає вплив } \\
\text { роздрібних торговельних } \\
\text { мереж. }\end{array}$ & $\begin{array}{l}\text { Інноваційний механізм управління у більшості } \\
\text { суб'єктів торговельної діяльності упроваджується } \\
\text { й діє безсистемно, переважно на основі особи- } \\
\text { стої інтуїції власників та керівників підприємств. } \\
\text { Системно керований інноваційний розвиток тор- } \\
\text { говельної сфери визначається зростанням домі- } \\
\text { нуючої ролі великих роздрібних торговельних } \\
\text { мереж, як правило, представників ТТНК. Інно- } \\
\text { ваційна діяльність значної кількості суб'єктів } \\
\text { торговельної діяльності пов'язана з відновленням } \\
\text { і зміною асортименту, удосконалюванням торго- } \\
\text { вельної реклами, викладкою товарів у торговому } \\
\text { залі, прийомами стимулювання продажів, від- } \\
\text { криттям нових магазинів тощо. }\end{array}$ \\
\hline $\begin{array}{l}\text { Характер } \\
\text { конкуренції } \\
\text { у сфері } \\
\text { роздрібної } \\
\text { торгівлі }\end{array}$ & $\begin{array}{l}\text { Рівень конкуренції по- } \\
\text { стійно зростає, все біль- } \\
\text { ший вплив на неї здій- } \\
\text { снюють закордонні ри- } \\
\text { тейли. }\end{array}$ & $\begin{array}{l}\text { Конкурентний тиск, що посилюється, стимулює } \\
\text { інноваційну активність роздрібних торговельних } \\
\text { підприємств, при цьому велика кількість суб'єктів } \\
\text { торгівлі (передусім дрібнороздрібних) має неви- } \\
\text { соку межу ї підвищення. Значна частина процес- } \\
\text { них і маркетингових інновацій, що з'являються } \\
\text { у сфері роздрібної торгівлі останніми роками, с } \\
\text { запозиченням закордонного досвіду. }\end{array}$ \\
\hline $\begin{array}{l}\text { Інноваційна } \\
\text { активність } \\
\text { вітчизняних } \\
\text { промислових } \\
\text { підприємств }\end{array}$ & $\begin{array}{l}\text { Рівень інноваційної ак- } \\
\text { тивності української про- } \\
\text { мисловості, шо забезпе- } \\
\text { чує товарне наповнення } \\
\text { роздрібної торгівлі, за- } \\
\text { лишається невисоким че- } \\
\text { рез відсутність державної } \\
\text { промислової політики й } \\
\text { методівстимулювання ін- } \\
\text { новаційної діяльності. }\end{array}$ & $\begin{array}{l}\text { Висока частка імпортних товарів в інноваційній } \\
\text { складовій товарних асортиментів торговельних } \\
\text { підприємств. }\end{array}$ \\
\hline
\end{tabular}

Джерело: сформовано на основі [8] 
В Україні нещодавно запровадили додаток «Дія». За допомогою цього цифрового документа українці мають можливість здійснювати подорожі країною залізничним та повітряним транспортом; отримувати медичне обслуговування; здійснювати банківські операції; отримувати адміністративні та інші державні послуги.

Запроваджена практика введення чіпів - крихітних пристроїв, що замінюють кредитні карти. Чіп управляє також принтером та іншими пристроями в процесі реалізації товарів.

Нові можливості у практиці торговельного обслуговування вітчизняних торгових підприємств в умовах поширення пандемії корона вірусу, повинні відкривати «розумні візки» (smartcart), які активно практикують закордонні підприємства, що представляють собою поєднання звичайних візків, сканерів, штрих-коду і комп'ютерів.

Магазинний візок X-Grip Wiper корейського дизайнера Кім Кван-Вонга довів, що питання безпеки користування засобами для відбору товарів в сучасних супермаркетах знято, адже дозволяє не ділитися ні з ким своїми ручними бактеріями, і не отримати аналогічних «подарунків» від оточуючих (на ручку магазинного візка прикріплено невеликий пристрій, усередині якого знаходяться ролики, просочені очищаючою рідиною).

На даний час в Україні є ще не багато суб'єктів, які готові активно запроваджувати інновації.

Компанія Fozzy Group направила свої зусилля на оновлення дизайну і планування торгових точок Сільпо, розширення торгового асортименту, застосування інноваційних концепцій в обслуговуванні споживачів (створення фуд-зони, розміщення в центрі торгової зали відкритої кухні «Страви світу», терміналів обслуговування. Крім цього, у мережі «Сільпо» розвивається напрям власного імпорту, в рамках якого в супермаркети поставляються вина, делікатеси, чай, кава, заморожені продукти, кондитерські вироби. Зважаючи на відсутність посередників, на такі продукти встановлюються ціни, що є привабливими для покупців, інше).

Інноваційна унікальність застосування в роботі супермаркетів Сільпо терміналу «Вектор» полягає в технології продажу - поєднання принципів cash\&carry, можливостей інтернет магазину і сенсорного інтерфейсу. Термінал «Вертер» дозволяє економити час, працювати 3 каталогом товарів, порівнювати товар, відбирати товар за параметрами, формувати замовлення, заповнювати форми, вести облік замовлень.

Така інновація є важливою, адже завдяки їй відбувається економія місця вітрин, оренди приміщення, економія в наймі працівників.

Основними перспективами діяльності компаніє є досягнення та утримування позиції одного з регіональних лідерів галузі у Західному регіоні України; зростання частки ринку компанії на ринку роздрібної торгівлі порівняно із основними конкурентами.

Висновки. Впровадження передових технологій та практик, що існують та активно практикують на даний момент провідні світові торгові компанії - один із основоположних принципів подальшого розвитку торгівлі в Україні.

Невід'ємною частиною в стратегічному управлінні процесом збуту товарів, послуг та обслуговування споживачів торгових підприємств повинні залишатись правила мерчандайзингу, складові комплексу маркетингу та інноваційні технології.

Інноваційним напрямком в діяльності сучасних торгових підприємств повинні бути програми, спрямовані на запровадження екологічних рішень при модернізації процесу роздрібного продажу товарів та обслуговування споживачів, впровадження енергозберігаючих технологій, вирішення екологічних проблем, поліпшення екологічної ситуації в Україні.

\section{Список використаних джерел:}

1. Закон України «Про ліцензування». URL: https://kodeksy.com.ua/dictionary/t/torgivlya.htm (дата звернення: 15.12.2020). 
2. Державна служба статистики України. URL: http://www.ukrstat.gov.ua (дата звернення: 15.12.2020).

3. Добуш 3.О. Стан і тенденції розвитку роздрібної торгівлі - детермінанта ефективності іï регулювання. Науковий вісник НЛТУ України. 2013. № 23.1. С. 248-253.

4. Топ-5 продуктових мереж України за кількістю магазинів і темпам відкриттів в 2018 році. URL: https://rau.ua/novyni/top-5-produktovyh-setej (дата звернення: 15.12.2020).

5. Міжнародна дослідницька мережа GfK Group URL: http://www.gfk.com/ua/ (дата звернення: 15.12.2020).

6. Тараненко О.О. Тенденції та чинники розвитку роздрібної торгівлі в Україні. Економічний простір. 2012. № 64. С. 126-131.

7. Мерчандайзинг як засіб формування імпульсу покупки. URL: dspace.nuft.edu.ua/jspui/ bitstream/123456789/11558/3/Merchandisin.pdf (дата звернення: 15.12.2020).

8. Каракай Ю.В. Маркетинг інноваційних товарів: монографія. Київ : КНЕУ, 2005. 226 с.

\section{References:}

1. Zakon Ukrainy Pro litsenzuvannia [Law of Ukraine «On licensing»]. Available at: https://kodeksy.com.ua/dictionary/t/torgivlya.htm (accessed 15 December 2020).

2. Derzhavna sluzhba statystyky Ukrainy. Kyiv: Informatsiino-analitychne ahentstvo. Available at: http://www.ukrstat.gov.ua (accessed 15 December 2020).

3. Dobush Z.O. (2013) Stan i tendentsii rozvytku rozdribnoi torhivli - determinanta efektyvnosti yii rehuliuvannia [The state and trends in the development of retail trade - a determinant of the effectiveness of its regulation]. Naukovyi visnyk NLTU Ukrainy, no. 23.1, pp. 248-253.

4. Top-5 produktovykh merezh Ukrainy za kilkistiu mahazyniv i tempam vidkryttiv v 2018 rotsi. Available at: https://rau.ua/novyni/top-5-produktovyh-setej (accessed 15 December 2020).

5. Mizhnarodna doslidnytska merezha GfK Group Available at: http://www.gfk.com/ua/ (accessed 15 December 2020).

6. Taranenko O.O. (2012). Tendentsii ta chynnyky rozvytku rozdribnoi torhivli v Ukraini [Trends and factors in the development of retail trade in Ukraine]. Ekonomichnyi prostir, no. 64, pp. 126-131.

7. Merchandaizynh yak zasib formuvannia impulsu pokupky. Available at: dspace.nuft.edu.ua/ jspui/bitstream/123456789/11558/3/Merchandising.pdf (accessed 15 December 2020).

8. Karakai Yu.V. (2005) Marketynh innovatsiinykh tovariv [Marketing of innovative goods]. Kyiv: KNEU. (in Ukrainian) 